\title{
Article \\ Surface Deformations Caused by the Convergence of Large Underground Gas Storage Facilities
}

\author{
Krzysztof Tajduś ${ }^{1, *(\mathbb{D}}$, Anton Sroka $^{1}$, Rafał Misa $^{1}{ }^{1}$, Antoni Tajdus ${ }^{2}$ and Stefan Meyer ${ }^{3}$ \\ 1 Strata Mechanics Research Institute, Polish Academy of Science, 30-059 Kraków, Poland; \\ sroka@imgpan.pl (A.S.); misa@imgpan.pl (R.M.) \\ 2 Faculty of Mining and Geoengineering, AGH University of Science and Technology, Mickiewicza 30 av., \\ 30-059 Kraków, Poland; tajdus@agh.edu.pl \\ 3 Salzgewinnungsgesellschaft Westfalen mbH \& Co. KG (SGW), 48683 Ahaus, Germany; \\ stefan.meyer@solvay.com \\ * Correspondence: tajdus@imgpan.pl; Tel.: +48-12637-62-00
}

Citation: Tajduś, K.; Sroka, A.;

Misa, R.; Tajduś, A.; Meyer, S. Surface Deformations Caused by the Convergence of Large Underground Gas Storage Facilities. Energies 2021, 14, 402.

https://doi.org/10.3390/ en14020402

Received: 19 November 2020

Accepted: 8 January 2021

Published: 12 January 2021

Publisher's Note: MDPI stays neutral with regard to jurisdictional clai$\mathrm{ms}$ in published maps and institutional affiliations.

Copyright: $(\odot 2021$ by the authors. Licensee MDPI, Basel, Switzerland. This article is an open access article distributed under the terms and conditions of the Creative Commons Attribution (CC BY) license (https:// creativecommons.org/licenses/by/ $4.0 /)$.

\begin{abstract}
The article presents a method of forecasting the deformation of the land surface over large fields of underground gas storage facilities located in salt caverns. The solution allows for taking into account many parameters characterising the operation of underground gas storage facilities, such as cavern processes (leaching, enlargement, operational, etc.), their depth, distribution, diameter, shape, and many others. The advantage of the applied method over other available options is the possibility of using it for large fields of caverns while keeping the calculations simple. The effectiveness of the method has been proven for predicted surface subsidence for the EPE field with 114 underground caverns. The hypothesis was compared with the measurement outcomes.
\end{abstract}

Keywords: underground storage; cavern; subsidence; surface deformation

\section{Introduction}

In recent decades, there has been an increase in the demand for natural gas in the world [1].

This has been noticed by the European Commission Directorate-General for Energy, which defined energy security as the ability of the gas transmission system to ensure continuous and reliable gas supplies to consumers on economic terms and the ability to face interruptions in natural gas supplies. This definition indicates that the actions of the EU state bodies should aim both at ensuring operational security (current at the time), tactical security (planned and predicted for a specific season) and strategic security (planned and predicted in subsequent years) [2].

Considering the fluctuations of natural gas consumption in an annual period, such as the increase in the autumn-winter period and subsequent decrease in the spring-summer period (Figure 1), operators have been forced to create systems to accumulate gas surpluses. This is partly because energy storage can play a pivotal role in future energy systems compatible with a carbon-neutral and environmentally friendly society.

In general, there are four types of underground gas storage facilities contained in: depleted reservoirs, aquifers, mines and salt caverns. Each type has its own physical characteristics such as; retention capability, porosity, permeability, and economic issues including site preparation and maintenance costs, deliverability rates, and cycling capability $[4,5]$. The most common natural gas storage type globally is depleted reservoirs because their greatest advantages are their wide availability and existing underground and surface infrastructure (existing wells, gathering systems, and pipeline connections) [6-8]. However, it is the gas storage facilities built in salt dome formations (salt caverns) that are currently building popularity. These storage facilities are characterised by significantly higher gas withdrawal rates than other types of UGS and may serve as peak gas storage 
facilities (withdrawal and injection cycles). Currently, 9\% of underground gas storage facilities worldwide are located in salt caverns. Table 1 presents the number of salt caverns fields in Europe.

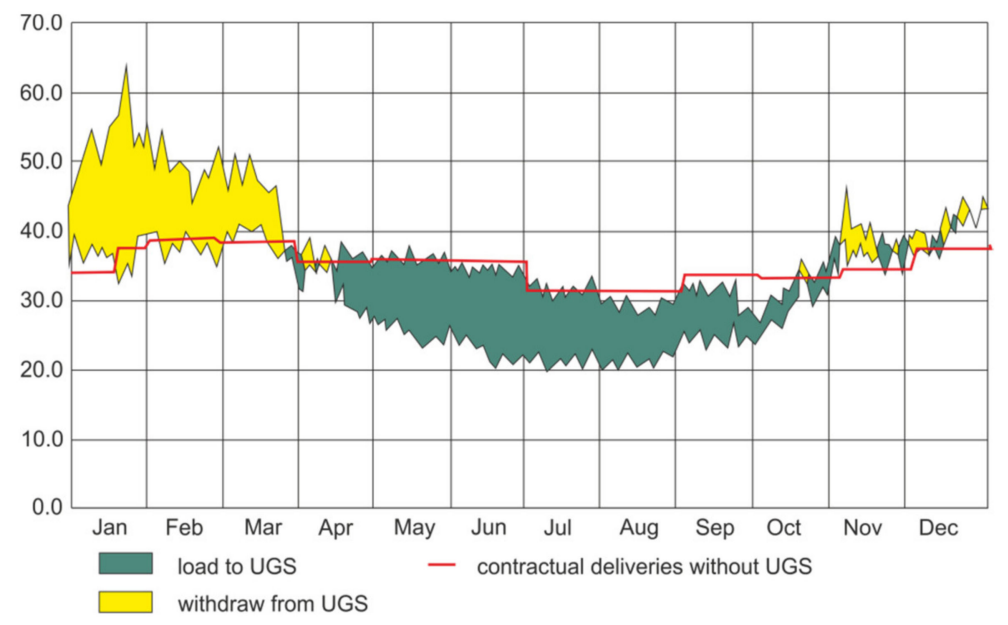

Figure 1. The course of demand and supply of high-methane natural gas in 2006; (UGS, underground gas storage) [3].

Table 1. The number and types of underground gas storage facilities (fields) located in selected European countries (source: own study based on [2]).

\begin{tabular}{ccc}
\hline Country & Underground Gas Storage (UGS) Facilities in Salt Caverns & (Sum) \\
\hline Belgium & 1 & 2 \\
Denmark & 1 & 2 \\
France & 3 & 15 \\
Germany & 21 & 46 \\
United Kingdom & 3 & 6 \\
Czech Republic & 1 & 7 \\
Poland & 2 & 9 \\
Portugal & 1 & 1 \\
\hline
\end{tabular}

These fields consist of a variety of caverns. For example, Solvay has 114 caverns in the EPE field (in Gronau-Epe-Germany), 31 production, 5 crude oil, 77 natural gas and 1 helium (as of 09/2019). However, the unquestionable advantage of gas (and oil) storage in salt caverns, i.e., their availability to cover short-term, very large gas deficits, has also become a problem for them. UGS operators in caverns, given their benefits, intensified the work of the caverns in terms of market instruments by creating a network of commercial storage of gas and oil. These activities led to frequent annual changes in pressure inside the caverns. The related injection, unloading and additional leaching caused a significant disruption of the cavern convergence process, including their significant acceleration [9].

The problem of the progressive accelerated convergence of salt caverns is currently very important for UGS operators. The correct method of forecasting the convergence and the related change in the state of rock mass deformation allows for the prevention of damage to the operating pipelines, damage to the surface transmission network, and the determining of the required period of leaching processes-i.e., restoring or increasing the storage volume, or specifying the periods of required echometric or geodetic measurements [10]. For example, for the mentioned EPE cavern field, the maximum measured subsidence of the land surface in 2013 slightly exceeded $700 \mathrm{~mm}$ [11].

The presented article shows a modern and effective method of predicting the deformation of the rock mass and the land surface above the used large cavern field. Presented calculation results were made at the end of 2019. Then, the forecasted deformation indicators were confirmed by geodesic measurements carried out by the cavern field operator 
(SWG Solvey Epe, Ahaus, Germany). The effectiveness of the forecast depends on the details of the information provided (including, among others, cavern dimensions, production phases, convergence rate), which allows for the advance determining of the potential environmental hazards associated with possible damage to the operating pipelines and leakage of the medium. This knowledge permits for preventive work to be carried out and thus the safety of the transmission of energy medium.

\section{Methods for Determining Changes in Rock Mass Deformation for Salt Caverns}

Many scientists have dealt with the influence of underground gas storage facilities located in salt caverns on the stress and deformation of the rock mass, its tightness and surface area [6,12-15]. This is related to the growing interest in this method of storing energy factors. Depending on the challenges faced by scientists, they used various tools, most suitable for obtaining satisfactory results. The literature contains many works in which the authors used numerical models to describe the behaviour of a single salt cavern. These analyses were mainly related to the problem of heterogeneity in the rock structure of the underground storage and the assessment of their tightness, among others [16]. The authors used various physical models for the description of the rock mass and the processes occurring in it; for example, in the work of [17] the authors have used Drucker-Prager constitutive law with equivalent Mohr-Coulomb parameters, including a tension cut-off with the WIPP creep model to simulate plastic yielding and creep. These calculations allowed for the determination of the deformations in the area of a single salt cavern with mudstone interbeds. A similar approach was presented by [18] in their work to describe the behaviour of a single horizontal cavern. They used the creep model with Mohr-Coulomb criterion. Wang et al. [13] carried out numerical analyses for the two adjacent caverns and their mutual influence on stability. Numerical analyses for determining the stability of the pillar separating the two adjacent caverns were also conducted [19] however, numerical methods were not the only engineering tool for assessing the behaviour of underground gas storage facilities [20]. The growing interest in neural networks encouraged scientists to use them also for UGS analyses [21]. Despite the popularity and significant advantages of the methods presented above, analytical methods have also found their place in the description of the changing state of stress and strain in the areas of underground salt caverns [22]. In the work of [23], the authors presented interesting analytical and numerical solutions for the hexagonal system of seven underground caverns. The authors analysed the optimal distribution of these caverns and their influence on the surrounding rock mass. Polański [24] carried out analyses of changes in the strain-stressing state of the caverns during thermal change, which is observed during gas injection and cavern emptying processes. The numerical analysis carried out for an exemplary cavern modelled by Norton's rheological model [15,24-26] showed that the thermal change implemented in the solutions affects the state of the cavern in a small range and should be taken into account when analysing the area up to $50 \mathrm{~m}$ from the cavern axis in detail (for caverns with a diameter of 30-35 m).

In previous work [27], the authors presented analytical solutions enabling the calculation of the volume of a single cavern, its capacity and convergence. Analytical methods are used especially when conducting analyses for large areas of cavern fields and when it comes to determining potential deformations of the ground surface $[28,29]$. The advantage of analytical solutions is the simplicity of building a model of the entire cavern field in the salt dome and taking into account their mutual relations and nature. However, this solution also has disadvantages. They are associated with one-parameter describing the nature of the rock mass. This assumption causes an inability to analyse rock mass stratification.

This deformation significantly affects the safety of pipelines and gas pipelines [30,31]. Examples of damage can be found in the works of, among others [32-35]. 


\section{Method of Surface Deformation Prediction for a Large Field of Salt Caverns}

As shown in the previous section, numerical modelling of cavern fields usually involves several caverns. This limitation is related to the number of elements and the calculation of equilibrium equations that a computational machine must perform in order to obtain a result. Therefore, in order to determine the deformation state of the rock mass and terrain surface for the whole cavern field covering more than 100 salt caverns, the authors used their own analytical solutions (Figure 2). They were based on the modified geometrical-integral condition of Knothe theory [36]. The modification was based on the basic assumptions presented by Sroka and Schober [37]. The size of the deposit element was determined in a way, so that the trough formed by the extraction of this element was practically matching the fundamental solution in the form of a Gaussian function and it allowed for, among other things, precise consideration of the three-dimensional geometry of the selected deposit, i.e., the variation in its thickness and depth and of other necessary information such as the distribution of pressure in the case of fluid deposit exploitation. That is why, based on presented research, simulations, and parameter identifications, a new methodology (modification) has been developed. The theoretical solution of modification was presented in the conference [29],

$$
S(r, z, t)=s_{\max }(z, t) \cdot \frac{R_{f}(z) \cdot R_{r}(z)}{r \cdot h} \cdot \tan \beta \cdot\left[F\left(\frac{r}{R_{f}(z)}\right)-F\left(\frac{r}{R_{r}(z)}\right)\right]
$$

where:

$$
\begin{gathered}
F\left(\frac{r}{R(z)}\right)=\int_{r / R(z)}^{\infty} \exp \left(-\pi \lambda^{2}\right) d \lambda \\
R_{r}(z)=R_{r} \cdot\left(\frac{z-z_{r}+c}{H_{r}+c}\right)^{n}, R_{r}=H_{r} \cdot \cot \beta, R_{f}(z)=R_{f} \cdot\left(\frac{z-z_{f}+c}{H_{f}+c}\right)^{n}, R_{f}=H_{f} \cdot \cot \beta .
\end{gathered}
$$

and:

$S(r, z, t)$-subsidence of surface point at moment $t$, situated in the ground level $z$ at a distance of $r$ from the cavern axis,

$s_{\max }(z, t)$-maximum subsidence at moment $t$,

$\mathrm{H}_{r}$-distance between the terrain surface and the depth of cavern roof,

$\mathrm{H}_{f}$-distance between the terrain surface and the depth of cavern floor,

$R_{r}$-parameter of the horizontal influence scale, so-called radius of main influences, calculated from the cavern roof,

$R_{f}$-radius of main influences, calculated from the cavern floor,

$h=H_{f}-H_{r}$-cavern's height,

$\beta$-so-called angle of main influences (Knothe 1953),

$\lambda$-coefficient of horizontal displacement,

$c$-coefficient/characteristics of cavern roof,

$n$-surface factor of the range of main influences of exploitation in the rock mass,

$z$-height on the terrain surface,

$z_{r}$-depth of cavern roof occurrence,

$z_{f}$-depth of cavern floor occurrence.

But it needed verifications. 


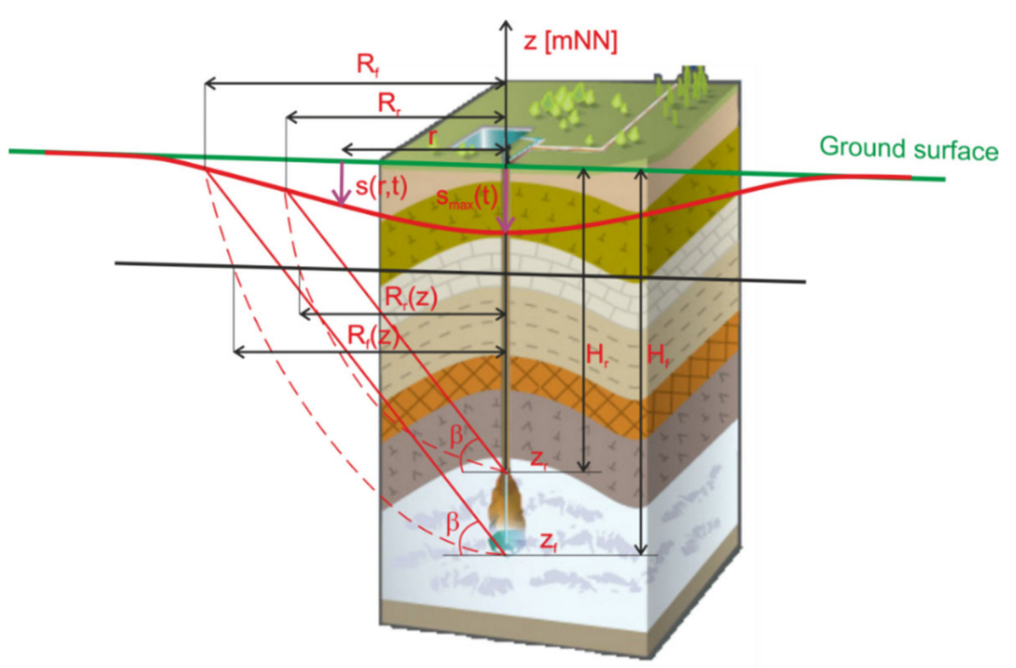

Figure 2. A subsiding trough above an exemplary salt cavern. (3D background is from https: //www.entrepose.com/en/geostock-sandia/expertise/).

The relationship between the maximum subsidence $S_{\max }(t)$ and the subsidence trough volume $M(t)$ can be presented as:

$$
M(t)=S_{\max }(t) \cdot R_{r}(z) \cdot R_{f}(z) .
$$

where:

$R_{r}(z)$-radius of main influences, calculated at any $z$ point in the strata from the cavern roof, and

$R_{f}(z)$-radius of main influences, calculated at any $z$ point in the strata from the cavern floor.

In the case of a cavern field, the calculation of any surface point subsidence is carried out while assuming a linear superposition, i.e., the summation of subsidence from individual caverns. The subsidence trough volume $M(t)$ depends on the volumetric convergence $K(t)$, the delaying effect of the overlying rock mass, and possible volume losses connected with the deformation of the overlying rock mass. The convergence in time may be described analytically using a logarithmic function or an exponential function [38].

Assuming an incremental leaching model, Sroka and Schober [37] ascertained that the subsidence trough volume on the surface may be described by the following formula:

$$
M(t)=a \cdot K(t-\Delta t) .
$$

The analyses of the subsidence results carried out in situ indicated that the a factor was practically equal to one, i.e., no volume losses occured in the rock mass [39].

The $S_{\max }(t)$ value also depends on the shape of the cavern (e.g., is it a cylinder, a sphere, a cone) and on the geometrical convergence model $[39,40]$. The results of the comparative calculations carried out lead to ascertaining that the maximum subsidence value may be determined using the formula (6) with a very good approximation:

$$
S_{\text {max }}(t)=\frac{a \cdot K(t-\Delta t)}{R_{r}(z) \cdot R_{f}(z)}
$$

where:

$K(t-\Delta t)$-volumetric convergence of cavern over time $t-\Delta t$,

$\Delta \mathrm{t}=\frac{1}{f}$ - delay time caused by the delaying action of the overlying rock mass.

The basic component of the computational model consists of the correct definition of the initial condition in the form of volumetric convergence of a single cavern [41]. 
The history of the operation of single caverns indicates that the leaching or enlargement phases may change multiple times [42]; also, the same pertains to the stored medium (petroleum or gas). In this connection, the multiphase cavern use model was adopted for the description of the convergence course in time, introducing the phases of leaching, standby (preparedness), operation and enlargement (Figure 3).

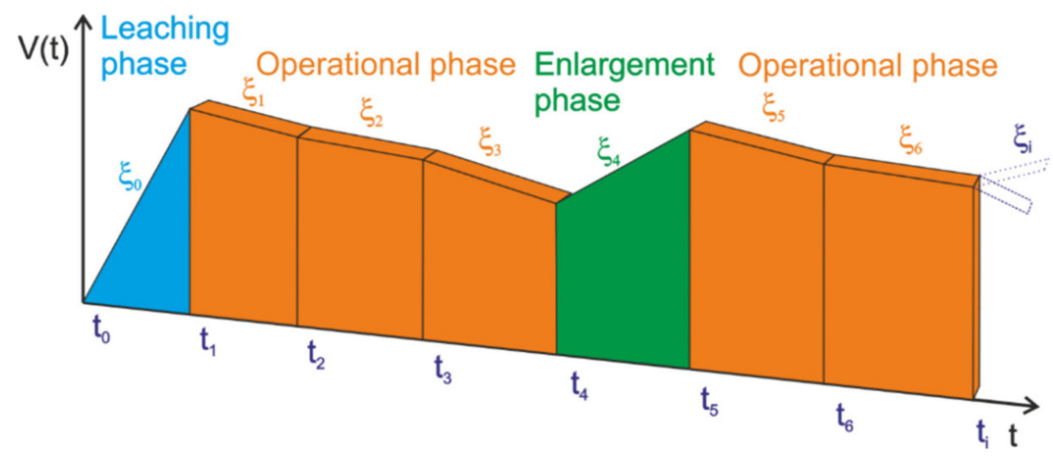

Figure 3. The schematic course of the use phases.

It is obvious that each phase leads to different convergence values, and thus to different values of the $\xi$ parameter. Examples of average values of the relative convergence rate $\xi$ depending on the production phase for the EPE cavern field are reported in Table 2 [11].

Table 2. List of average values of convergence rate [11].

\begin{tabular}{ccc}
\hline Production Phase & Yearly Convergence Rate (\%) & Time in Years \\
\hline Operation/Leaching & 0.6 & $7-10$ \\
Standby & 0.3 & $1-5$ \\
Storage (gas) & $0.8-1.6$ & $30-50$ \\
Storage (petroleum) & 0.2 & $30-50$ \\
\hline
\end{tabular}

When adopting the exponential model of the volumetric convergence process, the convergence increase for the $i$-th phase of use in this phase (Figure 3) may be calculated using the formula:

$$
\Delta K\left(t_{i}, t_{i+1}\right)=V\left(t_{i}\right) \cdot\left[1-\exp \left(-\xi_{i}\left(t_{i+1}-t_{i}\right)\right)\right] .
$$

Thus, the cavern volume at the end of the $i$-th phase of use equals:

$$
V\left(t_{i+1}\right)=V\left(t_{i}\right)-\Delta K\left(t_{i}, t_{i+1}\right)
$$

For the leaching phase, assuming the linear model of the leaching process, the convergence value may be calculated acc. to the Formula (9) for any time point during the leaching phase (with the assumption that $t_{0}<t<t_{1}$ and $T=t_{1}-t_{0}$ ):

$$
K(t)=\frac{V^{e}}{T} \cdot\left[\left(t-t_{0}\right)-\frac{1}{\xi_{0}}\left(1-\exp \left\{-\xi_{0} \cdot\left(t-t_{0}\right)\right\}\right)\right] .
$$

where:

$T$-leaching time,

$\xi_{0}$-relative volumetric convergence rate.

According to various literature sources [43], the $\xi_{0}$ values are in the range of:

$$
0.5 \% \leq \xi_{0} \leq 1.5 \%
$$

For a definite calculation of time $t$, convergence values for the operational phases should be added up between the beginning of the leaching $t_{0}$ and the $t-\Delta t$ time. 
The presented solution allows for the calculations to be carried out for every phase of cavern operation; among others, the following values may be calculated: convergence and free volume, subsidence, tilt, curvature, horizontal displacement, and deformation. The calculations may be carried out for any moment in time, not only for the final period of a given phase.

This solution has been successfully applied to many large cavern fields in Germany. In the next chapter, the authors present a sample case study.

\section{Prediction of Land Surface Deformation Along with Its Verification for an Exemplary Area of an Underground Gas Storage Facility}

The Epe underground gas storage facilities are built in the form of caverns leached in the salt dome. Its size is estimated at a cumulative capacity volume of 42 million $\mathrm{m}^{3}$ (114 salt caverns up to 2019) (Figure 4).

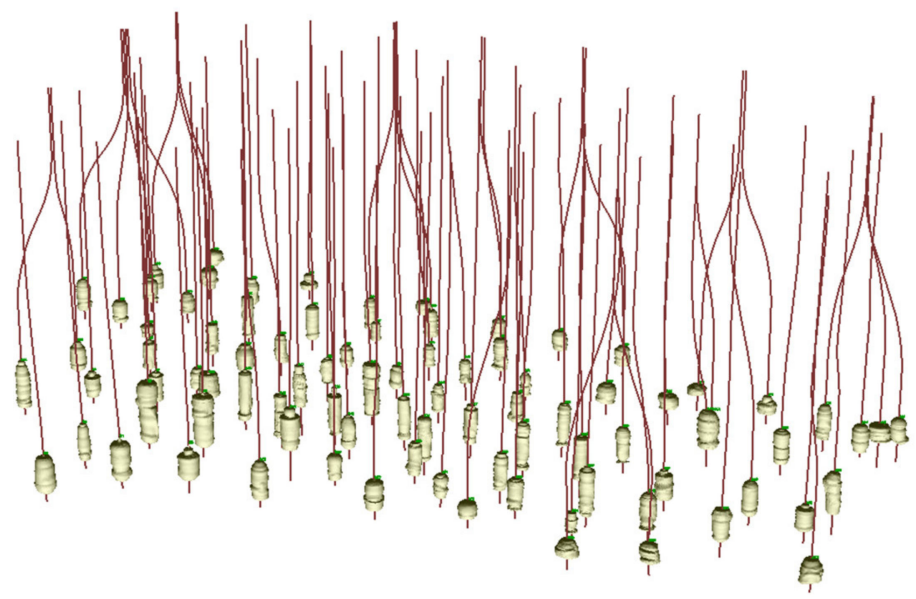

Figure 4. Example of a drawing of the caverns belonging to the EPE deposit.

Using the presented algorithm, based on the data provided by the cavern operator SGW (Salzgewinnungsgesellschaft Westfalen mbH \& Co. KG, Ahaus, Germany) the authors made forecast calculations of the future land surface deformation for the period to 12.30.2019.

All 114 caverns were included in the calculation and their geometries and the course of the phases of use in time. The data pertains to the time period starting in 1972. Exemplary data attributed to the cavern no. S_004, characterising its individual production phases, are presented in Table 3. The calculations were carried out for the following values of characteristic parameters of the EPE cavern field: angle of main influence- $\beta=34^{\circ}$, subsidence coefficient $-a=1.0$, and delay time $\Delta t=4$ months.

Table 3. Data characterising the individual production phases for the S_014 cavern.

\begin{tabular}{ccccc}
\hline Phase & $\begin{array}{c}\text { Date of the Phase } \\
\text { Beginning } \\
\text { (mm.dd.yyyy) }\end{array}$ & $\begin{array}{c}\text { End Date of } \\
\text { the Phase } \\
\text { (mm.dd.yyyy) }\end{array}$ & $\xi(\% /$ year) & $\begin{array}{c}\text { Free Volume of } \\
\text { the Cavern } \mathbf{( m}^{\mathbf{3}} \text { ) }\end{array}$ \\
\hline Leaching & 03.23 .1972 & 03.23 .1978 & 0.42 & 286100 \\
Enlargement & 03.23 .1978 & 09.30 .1983 & 0.33 & 347700 \\
Enlargement & 09.30 .1983 & 04.14 .1986 & 0.50 & 548700 \\
Enlargement & 04.14 .1986 & 04.03 .1992 & 0.33 & 613701 \\
Operational & 04.03 .1992 & 02.16 .2009 & 0.30 & 583412 \\
Enlargement & 02.16 .2009 & 05.16 .2010 & 0.37 & 647701 \\
Operational & 05.16 .2010 & 12.30 .2019 & 0.30 & 629267 \\
\hline
\end{tabular}

As a result of the calculations, the forecasted values of deformation indicators for the period of 12.30.2019 were obtained. The calculated maximum subsidence value for 
an exemplary field of 114 caverns equaled $81 \mathrm{~cm}$, while the measured value amounted to $79 \mathrm{~cm}$. In Figure 5, the course of the levelling point subsidence no. 211024 located above the cavern field in the period of 1975-2019 is presented as the comparison of theoretical course and geodetic measurements. Geodetic measurements have been carried out since 1973. Approximately 850 points were levelled each year. The levelling campaign was over $130 \mathrm{~km}$. In addition, 10 fixed points were located outside the subsidence trough.

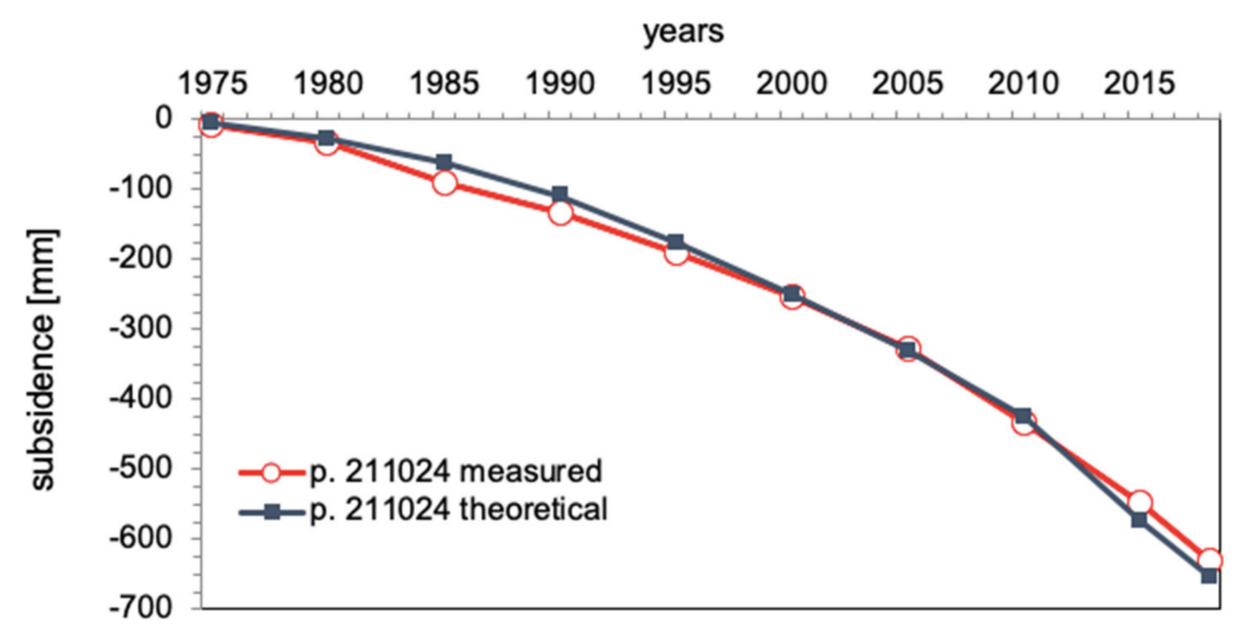

Figure 5. Comparison between theoretical (line with squares) and measured subsidence (line with circles) for the levelling point no. 211024 in the period of 1975-2019.

Other maximum values of the calculated factors amount to: max. tilt: $T_{\max }=0.53 \mathrm{~mm} / \mathrm{m}$,

max. horizontal displacement: $u_{\max }=342 \mathrm{~mm}$,

max. strain (compressive): $\left|\varepsilon^{-}\right|_{\max }=-0.43 \mathrm{~mm} / \mathrm{m}$,

max. strain (tensile): $\left|\varepsilon^{+}\right|_{\text {max }}=0.31 \mathrm{~mm} / \mathrm{m}$.

In Figure 6, a comparison of the subsidence results of theoretical calculations (solid line) and the results of subsidence measurements (dashed line) over the EPE cavern field for the time period of 12.30.2019 is shown. The location of point no. 211024 (red star) on the map in Figure 6 is presented.

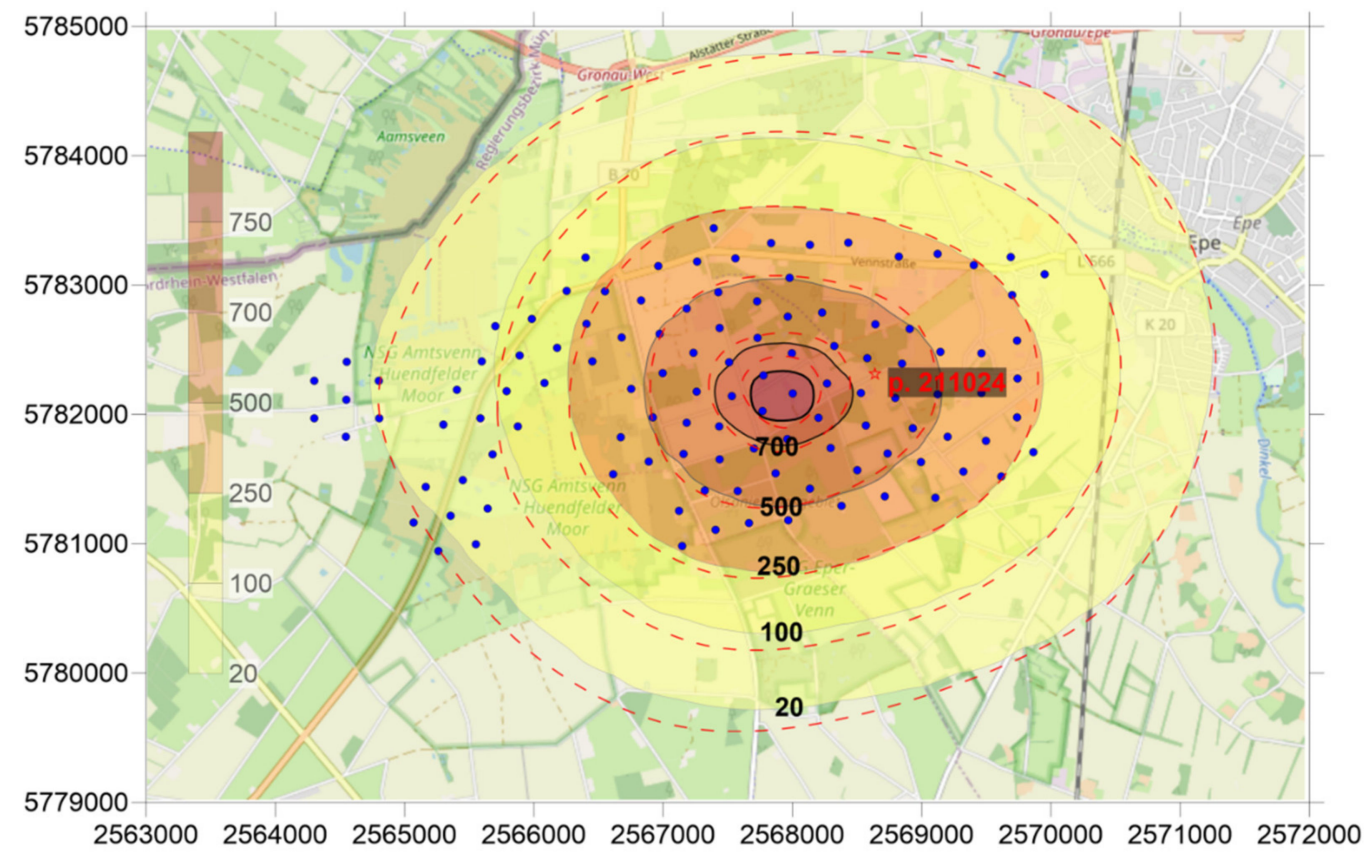

Figure 6. Comparison of the subsidence results of theoretical calculations (solid line) and the results of subsidence measurements in mm (dotted line) over the EPE cavern field, as per 12.30.2019 (the blue circles represent caverns). 
In Figure 7 results of theoretical calculations of horizontal displacement in $\mathrm{mm}$ over the EPE cavern field-as per 12.30.2019 are shown with three measuring points ( $\mathrm{u} 1, \mathrm{u} 2$ and u3) where horizontal displacements were measured.

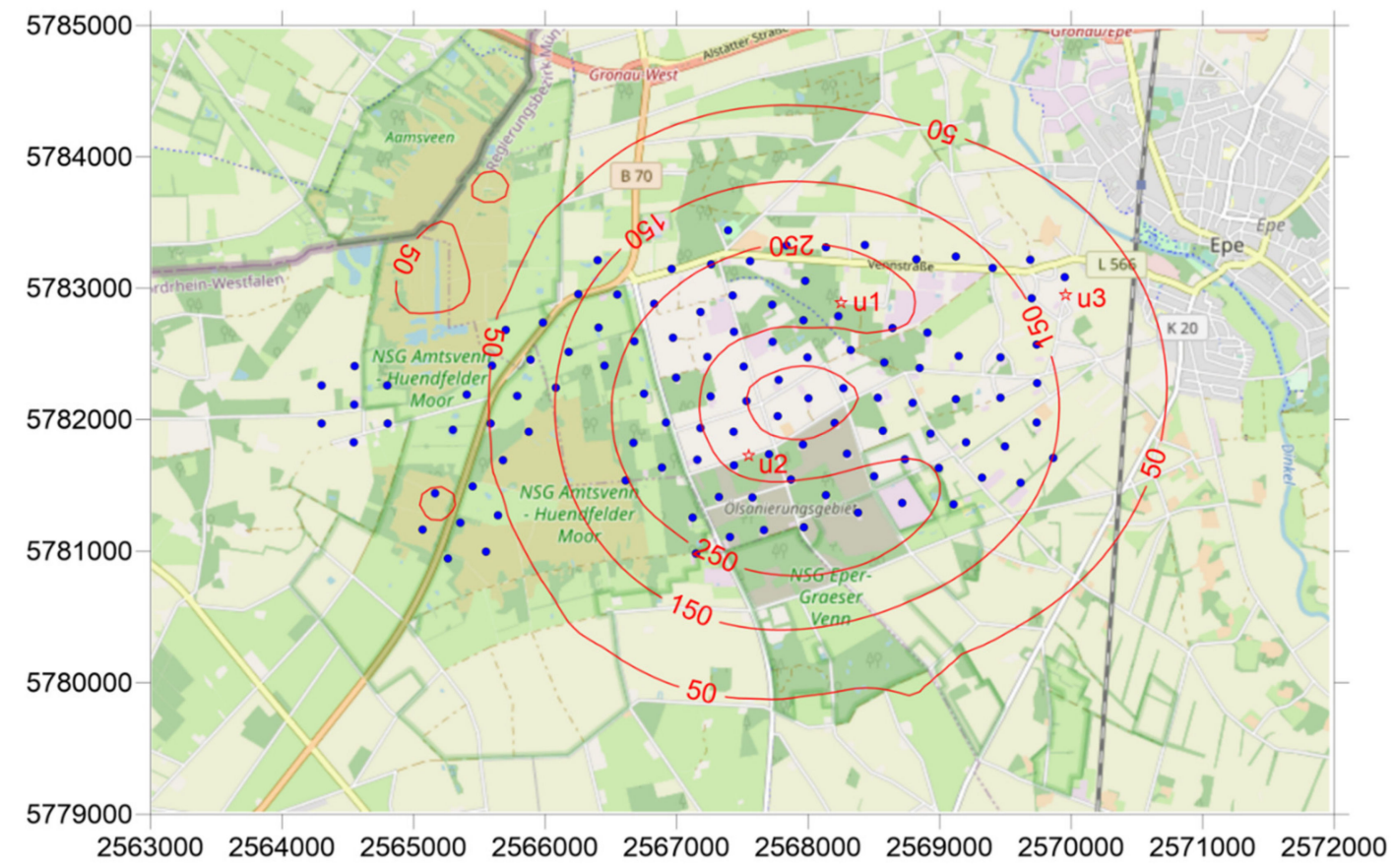

Figure 7. Results of theoretical calculations of horizontal displacement in mm over the EPE cavern field, as per 12.30.2019.

In Table 4, comparison of calculated and measured data for 3 example points for horizontal displacements for three different time periods (2006-2019, 2003-2016 and 20002016) with their differences in $\mathrm{cm}$ are presented.

Table 4. Comparison of calculated and measured data for 3 example points for horizontal displacements.

\begin{tabular}{ccccc}
\hline Point & $\begin{array}{c}\text { Period of } \\
\text { Measurement }\end{array}$ & $\begin{array}{c}\text { Displacement } \\
\text { Measured } \mathbf{( c m )}\end{array}$ & $\begin{array}{c}\text { Displacement } \\
\text { Calculated } \mathbf{( c m )}\end{array}$ & Difference (cm) \\
\hline u1 & $2006-2019$ & 15.7 & 16.9 & 1.2 \\
u2 & $2003-2016$ & 20.3 & 17.9 & -2.4 \\
u3 & $2000-2016$ & 8.8 & 7.2 & -1.6 \\
\hline
\end{tabular}

The data shown in Figures 5-7 and Table 4 confirm that the mathematical model proposed in this paper is able to describe the process of subsidence of the ground surface over a large cavern field in a salt rock mass relatively well and sufficiently accurately.

\section{Conclusions}

Recently the prediction of UGS facilities inducted surface problem is becoming increasingly important every year. Changes in the use of underground gas storage and frequent fluctuations of the pressure inside the caverns cause stress-strain imbalance. This creates an increase in the velocity of convergence of surrounding salt rock mass. The consequence of this behaviour is the failure of salt caverns or damage in pipelines (operating and transport).

The application of the presented method allows for the determination of future deformations of the ground surface, taking into account the processes in the cavern (leaching, enlargement, operational, etc.). The results of these calculations can be easily applied to 
analysing changes in the stress of underground gas storage infrastructure objects such as pipelines or other construction objects.

Despite necessary geometrical and physical idealisations related to the cavern geometry, course of convergence, and phases of operation, comparative computations performed for the EPE cavern field with its 114 caverns, have fully confirmed the value and the integrity of the presented solution.

Author Contributions: Conceptualization, K.T., A.S. and R.M.; methodology, A.S., K.T. and R.M.; software, K.T., A.S. and R.M.; validation, K.T., A.S., R.M., A.T. and S.M.; formal analysis, K.T., A.S. and R.M.; investigation, K.T., A.S., R.M., A.T. and S.M.; resources, A.S. and S.M.; data curation, A.S. and A.T.; writing-original draft preparation, R.M.; writing-review and editing, K.T. and R.M.; visualization, R.M.; supervision, A.S. and A.T.; project administration, A.S. and A.T. All authors have read and agreed to the published version of the manuscript.

Funding: This research received no external funding.

Institutional Review Board Statement: Not applicable.

Informed Consent Statement: Informed consent was obtained from all subjects involved in the study.

Data Availability Statement: The data presented in this study are available on request from the corresponding author. The data are not publicly available due to company's policy.

Conflicts of Interest: The authors declare no conflict of interest.

\section{References}

1. Kan, S.; Chen, B.; Wu, X.; Chen, Z.M.; Chen, G. Natural gas overview for world economy: From primary supply to final demand via global supply chains. Energy Policy 2019, 124, 215-225. [CrossRef]

2. IEA. Gas Information. Available online: https://www.iea.org/subscribe-to-data-services/natural-gas-statistics (accessed on 12 September 2020).

3. Matkowski, A.; Musiał, P. Systemowe magazyny gazu w Polsce. Arch. Energetyki 2012, 42, 81-92.

4. EIA: U.S. Energy Information Administration. Available online: https:/ / www.eia.gov/ (accessed on 12 September 2020).

5. Verga, F. What's conventional and what's special in a reservoir study for underground gas storage. Energies 2018, 11, 1245. [CrossRef]

6. Cala, M.; Cyran, K.; Kowalski, M.; Wilkosz, P. Influence of the anhydrite interbeds on a stability of the storage caverns in the mechelinki salt deposit (Northern Poland). Arch. Min. Sci. 2018, 63, 1007-1025. [CrossRef]

7. Cyran, K. Insight into a shape of salt storage caverns. Arch. Min. Sci. 2020, 65, 363-398. [CrossRef]

8. Ślizowski, J.; Urbańczyk, K. An attempt to asses suitability of middle-poland salt domes for natural gas storage/ocena przydatności środkowopolskich wysadów solnych do magazynowania gazu ziemnego. Arch. Min. Sci. 2012, 57, 335-349. [CrossRef]

9. Korzeniowski, W.; Poborska-Młynarska, K.; Skrzypkowski, K.; Zagórski, K.; Chromik, M. Cutting niches in rock salt by means of a high-pressure water jet in order to accelerate the leaching of storage caverns for hydrogen or hydrocarbons. Energies 2020, 13, 1911. [CrossRef]

10. Bhatka, T.; Usmani, A.; Mandal, A.; Nanda, A. Wedge failure analysis and remedial measures in large unlined rock cavern: A case study. Arch. Min. Sci. 2018, 63, 963-974. [CrossRef]

11. Hengst, G. Monitoring der durch Kavernenkonvergenz induzierten Bodensenkungen unter Betrachtung ihrer Wirkungen auf die ökologischen Zusammenhänge. Geokinematischer Tag 2014, 15, 237-251.

12. Wang, T.; Yang, C.; Yan, X.; Li, Y.; Liu, W.; Liang, C.; Li, J. Dynamic response of underground gas storage salt cavern under seismic loads. Tunn. Undergr. Space Technol. 2014, 43, 241-252. [CrossRef]

13. Wang, T.; Yang, C.; Ma, H.; Li, Y.; Shi, X.; Li, J.; Daemen, J. Safety evaluation of salt cavern gas storage close to an old cavern. Int. J. Rock Mech. Min. Sci. 2016, 83, 95-106. [CrossRef]

14. Wang, T.; Yang, C.; Chen, J.; Daemen, J. Geomechanical investigation of roof failure of China's first gas storage salt cavern. Eng. Geol. 2018, 243, 59-69. [CrossRef]

15. Wang, T.; Ma, H.; Shi, X.; Yang, C.; Zhang, N.; Li, J.; Ding, S.; Daemen, J. Salt cavern gas storage in an ultra-deep formation in Hubei, China. Int. J. Rock Mech. Min. Sci. 2018, 102, 57-70. [CrossRef]

16. Yang, C.; Wang, T.; Ma, H.; Li, Y.; Shi, X.; Daemen, J.J.K. Feasibility analysis of using horizontal caverns for un-derground gas storage: A case study of Yunying salt district. J. Nat. Gas Sci. Eng. 2016, 36, 252-266. [CrossRef]

17. Wang, G.; Guo, K.; Christianson, M.; Konietzky, H. Deformation characteristics of rock salt with mudstone interbeds sur-rounding gas and oil storage cavern. Int. J. Rock Mech. Min. Sci. 2011, 48, 871-877. [CrossRef]

18. Wang, T.; Yang, C.; Shi, X.; Ma, H.; Li, Y.; Yang, Y.; Daemen, J. Failure analysis of thick interlayer from leaching of bedded salt caverns. Int. J. Rock Mech. Min. Sci. 2015, 73, 175-183. [CrossRef] 
19. Wang, T.; Yang, C.; Yan, X.; Daemen, J. Allowable pillar width for bedded rock salt caverns gas storage. J. Pet. Sci. Eng. 2015, 127, 433-444. [CrossRef]

20. Wang, C.; Zhang, Q.Y.; Xiang, W. Physical and numerical modeling of the stability of deep caverns in tahe oil field in China. Energies 2017, 10, 769. [CrossRef]

21. Thoraval, A.; Lahaie, F.; Brouard, B.; Berest, P. A generic model for predicting long-term behavior of storage salt caverns after their abandonment as an aid to risk assessment. Int. J. Rock Mech. Min. Sci. 2015, 77, 44-59. [CrossRef]

22. Xie, P.; Wen, H.; Wang, G. An analytical solution of stress distribution around underground gas storage cavern in bedded salt rock. J. Renew. Sustain. Energy 2018, 10, 34101. [CrossRef]

23. Staudtmeister, K.; Rokahr, R. Rock mechanical design of storage caverns for natural gas in rock salt mass. Int. J. Rock Mech. Min. Sci. 1997, 34, 300.e1-300.e13. [CrossRef]

24. Polański, K. Numerical Calculations of Main Stress in the Rock Massif Around Salt Cavern for Compressed Air Storage. In Proceedings of the IOP Conference Series: Earth and Environmental Science, Kraków, Poland, 14-17 November 2017; Volume 214, p. 12079.

25. Ma, H.; Yang, C.; Qi, Z.; Li, Y.; Hao, R. Experimental and Numerical Analysis of Salt Cavern Convergence in Ultra-Deep Bedded Formation. In Proceedings of the 46th US Rock Mechanics/Geomechanics Symposium, Chicago, IL, USA, 24-27 June $2012 ; 2012$.

26. Lindvall, A. Modeling and Simulation of Creep in a Thermal Energy Storage Unit. Master's Thesis, Chalmers University of Technology, Gothenburg, Sweden, 2020.

27. Ślizowski, J.; Lankof, L.; Urbańczyk, K.; Serbin, K. Potential capacity of gas storage caverns in rock salt bedded deposits in Poland. J. Nat. Gas. Sci. Eng. 2017, 43, 167-178. [CrossRef]

28. Zander-schiebenhöfer, D.; Roordink, P.; Gasunie, N.V.N. Subsidence modelling for the zuidwending cavern field sub-sidence modelling for the zuidwending cavern field. In Proceedings of the Solution Mining Research Institute Fall 2017 Technical Conference, Münster, Germany, 25-26 September 2017.

29. Sroka, A.; Misa, R.; Tajduś, K. Calculation of convergence induced rock mass and ground surface movements in salt caverns for storage of liquid and gaseous energy carriers. In Geomechanics and Geodynamics of Rock Masses; CRC Press: Boca Raton, FL, USA, 2018; pp. 629-634.

30. Xia, M.; Zhang, H. Stress and deformation analysis of buried gas pipelines subjected to buoyancy in liquefaction zones. Energies 2018, 11, 2334. [CrossRef]

31. Albusoda, B.S.; Abbas, H.O. Numerical Modelling of Buried Steel Pipeline Overlaying Expansive Soil. In Proceedings of the 1st International Scientific Conference of Engineering Sciences-3rd Scientific Conference of Engineering Science (ISCES), Diyala, Iraq, 10-11 January 2018; pp. 281-286.

32. Kouretzis, G.P.; Karamitros, D.K.; Sloan, S.W. Analysis of buried pipelines subjected to ground surface settlement and heave. Can. Geotech. J. 2015, 52, 1058-1071. [CrossRef]

33. Sarvanis, G.C.; Karamanos, S.A.; Vazouras, P.; Dakoulas, P.; Mecozzi, E.; Lucci, A. Soil-Pipe Interaction Models for the Simulation of Buried Steel Pipeline Behaviour Against Geohazards. In Proceedings of the International Conference on Offshore Mechanics and Arctic Engineering-OMAE, Trondheim, Norway, 25-30 June 2017; Volume 5B-2017, pp. 1-10. [CrossRef]

34. Zhang, J.; Liang, Z.; Zhao, G. Mechanical behaviour analysis of a buried steel pipeline under ground overload. Eng. Fail. Anal. 2016, 63, 131-145. [CrossRef]

35. Rusek, J. The Point Nuisance Method as a decision-support system based on bayesian inference approach. Arch. Min. Sci. 2020, $65,117-127$.

36. Knothe, S. Effect of time on formation of basin subsidence. Arch. Min. Steel Ind. 1953, 1, 1-7.

37. Sroka, A.; Schober, F. Die Berechnung der maximalen Bodenbewegungen über kavernenartigen Hohlräumen unter Berücksichtigung der Hohlraumgeometrie. Kali Steinsalz 1982, 4, 273-277.

38. Sroka, A. Abschätzung Einiger Zeitlicher Prozesse im Gebirge. In Proceedings of the Schriftenreihe Lagerstättenerfassung und-Darstellung, Bodenbewegungen und Bergschäden, Ingenieurvermessung, Kolloquium, Leoben, Austria, 15-16 November 1984; pp. 103-132.

39. Hartmann, A. Ein Beitrag zur Überwachung von Kavernenanlagen. Master's Thesis, Technische Universität Clausthal, Clausthal, Germany, 15 June 1984.

40. Haupt, W.; Sroka, A.; Schober, F. Die Wirkung Verschiedener Konvergenzmodelle für Zylinderförmige Kavernen auf die Übertägige Senkungsbewegung. Das Markscheidewesen 1983, 90, 159-164.

41. Serbin, K.; Ślizowski, J.; Urbańczyk, K.; Nagy, S. The influence of thermodynamic effects on gas storage cavern convergence. Int. J. Rock Mech. Min. Sci. 2015, 79, 166-171. [CrossRef]

42. Khaledi, K.; Mahmoudi, E.; Datcheva, M.; Schanz, T. Stability and serviceability of underground energy storage caverns in rock salt subjected to mechanical cyclic loading. Int. J. Rock Mech. Min. Sci. 2016, 86, 115-131. [CrossRef]

43. Kamiński, P.; Czaja, P. An innovative solution to counteract convergence of shaft lining in rock salt strata. Arch.Min. Sci. 2019, 64, 429-445. [CrossRef] 